University of Chicago Law School

Chicago Unbound

\title{
Why Does the Public Cooperate with Law Enforcement? The Influence of the Purposes and Targets of Policing
}

Tom R. Tyler

Stephen J. Schulhofer

Aziz Huq

Follow this and additional works at: https://chicagounbound.uchicago.edu/public_law_and_legal_theory

Part of the Law Commons

Chicago Unbound includes both works in progress and final versions of articles. Please be aware that a more recent version of this article may be available on Chicago Unbound, SSRN or elsewhere.

\section{Recommended Citation}

Tom R. Tyler, Stephen J. Schulhofer \& Aziz Huq, "Why Does the Public Cooperate with Law Enforcement? The Influence of the Purposes and Targets of Policing" (University of Chicago Public Law \& Legal Theory Working Paper No. 339, 2011).

This Working Paper is brought to you for free and open access by the Working Papers at Chicago Unbound. It has been accepted for inclusion in Public Law and Legal Theory Working Papers by an authorized administrator of Chicago Unbound. For more information, please contact unbound@law.uchicago.edu. 


\section{CHICAGO}

Public LaW and Legal Theory Working Paper No. 339

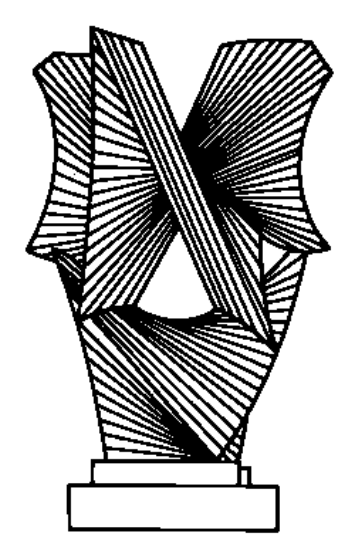

\section{WHy DOES THE PUBLIC COOPERATE WITH LAW ENFORCEMENT? THE INFLUENCES OF THE PURPOSES AND TARGETS OF POLICING}

Aziz Z. Huq, Tom R. Tyler, and Stephen J. Schulhofer

\section{THE LAW SCHOOL THE UNIVERSITY OF CHICAGO}

February 2011

This paper can be downloaded without charge at the Public Law and Legal Theory Working Paper Series: http://www.law.uchicago.edu/academics/publiclaw/index.html and The Social Science Research Network Electronic Paper Collection. 
Why does the public cooperate with law enforcement? The influence of the purposes and targets of policing

\author{
Aziz Z. Huq \\ Tom R. Tyler \\ Stephen J. Schulhofer
}

[forthcoming Psychology, Public Policy \& Law]

Author note. Aziz Huq, Assistant Professor, Law School, University of Chicago. Tom Tyler, University Professor, Psychology Department and Law School, New York University. Stephen Schulhofer, Professor, Law School, New York University. Correspondence: huq@uchicago.edu; 1111 East 60 ${ }^{\text {th }}$ Street, Chicago, IL 66037, USA (+1-773-702-9566(p); +1-773-702-0730(f)).

This research was supported by the National Science Foundation; the National Institute of Justice; and the Open Society Institute. 


\begin{abstract}
This study addresses the extension of the "procedural justice" model for understanding public cooperation with law enforcement to new policing contexts and new minority populations. The study draws on four recent surveys of public reactions to policing against crime or against terrorism across different populations to examine whether the changing purpose of policing, or changes in the communities targeted for heightened policing have an effect on how cooperative behaviors are elicited.

This paper presents evidence that procedural justice mechanisms are robust across a variety of contexts and populations in the United States. Three issues in particular are addressed. First, whether the procedural justice model applies across policing functions and policed populations. Second, whether the perception that another group is the target of disproportionate policing efforts has any effect on the cooperation behavior of a non-targeted population. And third, whether people attend to different aspects of policing behavior if their community is targeted for heightened policing attention.
\end{abstract}

Keywords: procedural justice, legitimacy, policing, terrorism 


\section{PURPOSES AND TARGETS OF POLICING}

\section{Introduction}

Past decades have seen large advances in the understanding of public attitudes toward the police and of the determinants of public order. Methodologically diverse empirical studies have identified the importance of "procedural justice" mechanisms in shaping both compliance with the law (Tyler, 2006b, 2007) and cooperation with law enforcement (Tyler \& Fagan, 2008). That model emphasizes the value of engaging communities in efforts to manage crime. It suggests such engagement occurs to the greatest extent when the police exercise their authority through procedures evaluated as fair by those who experience them.

Policing strategies, however, have changed recently along two axes. First, American police are now responding to a new problem-terrorism rather than ordinary crime. People have normative and political judgments about terror that diverge from their judgments about crime. These may influence their responses to policing measures directed against terrorism. Second, past policing investments have focused on racial minorities (particularly African-Americans) whereas counterterrorism policing resources are disproportionately directed at a minority defined by perceived religious affiliationMuslim Americans. New factors-in particular divergent religious or political ideologies; the experience of migrating to America (Cashin, 2010; Gottschald \& Greenberg, 2008; Lee, Gibbons, Thompson \& Timani, 2009; and Love, 2009); and past experiences with law enforcement in non-U.S. contexts-may influence this group's responses to policing. It therefore cannot be assumed that the procedural justice literature of past decades explains public cooperation in this new context.

This paper explores whether (and how) the procedural justice model translates into these emerging policing contexts. The study tests the extension of that model by drawing on post-September 11, 2001, random-sample surveys of both Muslim and nonMuslim residents of New York City that examine reactions to both anti-crime and antiterror policing. The study therefore allows for comparisons based on different policing purposes and variation in the most heavily policed populations.

The multiple data sets also enable comparative analysis of the effect on the majority of targeting a minority within the population. The procedural justice model 


\section{PURPOSES AND TARGETS OF POLICING}

suggests that people focus upon the fairness of policing procedures. Both policing against crime and policing against terror, however, involve a focus upon particular minority populations that are typically small in numbers and both economically and politically disadvantaged. Hence, an important issue in evaluating procedural justice models is whether the members of majority groups react negatively to unfair procedures directed at minority groups to which they do not belong. The nature and extent of such reactions may determine the sustainability of targeted policies that are experienced by minorities as unfair. This study examines this question by comparing two such situations: majority reactions to anti-crime policies directed toward African-Americans and Hispanics and to anti-terror policies directed at Muslim-Americans.

The study builds upon two prior investigations. First, Tyler and Fagan (2008) studied how different ethnic groups in New York evaluated policing tactics used against ordinary crime. Second, Tyler, Schulhofer and Huq (2010) explored the perception of counterterrorism policing tactics directed at Muslim Americans in New York. This study compares findings from these investigations with data from two additional surveys of (a) Muslims evaluating police efforts against ordinary crime and (b) non-Muslims evaluating police counterterrorism efforts.

Drawing on these four surveys, this study addresses three questions. First, does the procedural justice model effectively capture the dynamics of public responses to policing across populations and policing purposes? Ordinary crime and terrorism have different distributions of harm. They also lead to different distributions of policing resources across communities. By comparing populations it is possible to test the hypothesis that both those targeted by policing tactics and those who are not targeted react to policing by evaluating the procedural justice of police tactics. It is further possible to determine whether different evaluations of the harms caused by crime and terrorism lead to different public responses to police.

The second question is an extension of the first: Are the evaluations and actions of those who are not affected by policing tactics influenced by the manner in which the police treat members of other affected groups? Past studies of ordinary crime control have isolated a "spillover" effect from the procedural unjust treatment of minorities on to the perceptions and responses of majority community members (Tyler \& Wakslak, 2004). 


\section{PURPOSES AND TARGETS OF POLICING}

There is a question whether this spillover is observed in other policy areas and with respect to other minority groups.

Finally, the procedural justice model has identified various components of perceived police behavior that influence public responses to law enforcement. Earlier studies demonstrate that when people are dealing with legal authorities they consider different procedural elements to be important in the context of different kinds of interactions (Tyler, 1988). In the case of conflict, "voice” is perceived as central to fair procedures for resolving conflicts. By contrast, "trust in the authority" matters the most when people ask an authority to solve a problem. Other studies comparing ethnic groups further suggest that while these groups all view procedural justice as important, they diverge in subtle ways in terms of which aspects of police behavior they use as metrics of procedural justice (Tyler, 2001, 2005; Tyler \& Huo, 2002). This study extends the consideration of this issue by examining whether Muslim Americans judge procedural justice differently from previously studied ethnic groups. Although they are themselves ethnically and economically diverse, Muslims share a common religious background that may be distinct from the "Western" model broadly shared by White and minority group members in the United States.

\section{Policing and public cooperation: The "procedural justice" model and its alternatives}

The "procedural justice” model of policing contends that people's reactions to law enforcement are shaped primarily by evaluations of the fairness of police conduct. In particular, people are concerned with whether decisions are made through fair procedures and whether people are treated in interpersonally fair ways during the decision-making process.

This model further proposes that procedural justice induces a belief in the legitimacy of the police, i.e. trust and confidence in the police and the view that they ought to be obeyed (Sunshine and Tyler, 2003; Lind \& Tyler, 1998). Legitimacy is “a belief" with behavioral consequences: It induces people to defer to authorities (Tyler,2006a) and engage in voluntary cooperation with the police (Tyler \& Fagan, 2008; Tyler, Schulhofer \& Huq, 2010). 


\section{PURPOSES AND TARGETS OF POLICING}

Proposed alternatives to the procedural justice model focus on instrumental judgments. In the case of ordinary crime, one alternative links reactions to the police to estimates of the ability of the police to identify and apprehend those who break the law, i.e., to a logic of deterrence. Another focuses upon the effectiveness of the police in managing crime and social order. In either case, to motivate public behavior the police need to achieve instrumental objectives. In the counterterrorism context, there are two relevant instrumental metrics: whether terrorism is perceived to be a serious problem, and whether the police are viewed as effective in managing terrorism risks.

Previous studies suggest that a procedural justice model explains public cooperation better than a model grounded on the view that people make cooperation judgments based on their views about the marginal expected costs or benefits of cooperation (Becker, 1976).

Past empirical work also suggests the procedural justice model provides a powerful tool for describing the responses of both majority and minority groups (e.g., African-Americans, Hispanics) to ordinary crime (Sunshine \& Tyler, 2003; Tyler, 2006a; Tyler \& Fagan; 2008). A recent study of Muslim-Americans residing in New York City tested procedural justice accounts of cooperation against instrumental explanations that rely on calculations of costs and benefits (Tyler, Schulhofer \& Huq, 2010). That study concluded that procedural justice shapes Muslim Americans' attitudes and behaviors toward counterterrorism policing both directly and also due to its influence on legitimacy beliefs. In contrast, the study found only weak support for instrumental mechanisms. People did not cooperate based on whether they believed that the police were effective in dealing with terrorism either in terms of their ability of stop attacks. They also were not more likely to cooperate when they thought terrorism was a serious problem. Nor did the study find empirical support for the proposition that religious identity or experience in other nations diluted procedural justice mechanisms. Similar procedural justice effects have been identified in a recent study of British Muslims in London (Huq, Tyler \& Schulhofer, unpub. m.s.).

While these studies supported the application of the procedural justice model to terrorism, they did not systematically examine the influence of the nature of the policing task or the composition of the policed population on procedural justice assessments. 


\section{PURPOSES AND TARGETS OF POLICING}

Further, the finding that Muslim Americans respond to procedural justice mechanisms does not mean that non-Muslims will respond in the same way in regard to counterterrorism policing. It is possible that non-Muslims will be less sensitive to procedural justice than Muslims in respect to policing against terrorism because the former are more likely to view terrorism as especially salient, harmful, or morally odious. Alternatively, non-Muslims may discount the costs of counterterrorism because they believe the latter will be imposed disproportionately on a minority group of which they are not members. Finally, even if procedural justice mechanisms are detected for both the policing of non-Muslims for crime control ends and the policing of Muslims for counterterrorism goals, that does not show that different groups, in the context of different policing efforts, will focus on the same aspects of police behavior when defining fairness. Procedural justice may have different antecedents in different contexts.

This study supplements past investigations with new data about the determinants of Muslim Americans’ reactions to everyday policing and of non-Muslims’ responses to counterterrorism policing. Joint consideration of these four combinations of policing purpose and targets-i.e., combinations of non-Muslims/crime; non-Muslims/terrorism; Muslims/crime; Muslims/terrorism—enables a systematic examination of how context shapes the role of procedural justice in policing. In particular, by examining carefully the influence of minority-group targeting and different policing functions (crime control v. counterterrorism) this study aims to extend prior studies about procedural justice mechanisms.

\section{II. $\quad$ Post-September 2001 changes to the policing function and to police targets}

Since the 11 September 2001 (“9/11”) terrorism attacks on New York and Washington, the police in Western democracies have been asked to perform terrorism prevention as well as crime control functions (Weisburd et al., 2009; Clarke, 2007). The new counterterrorism function aims to prevent terrorist activity planned both overseas and domestically. Between May 2009 and August 2010, one Congressional study identified nineteen "homegrown” terrorist conspiracies in the United States (Bjelopera \& Randol, 2010). There has been little empirical investigation, however, of how this new policing against terror functions (but see results in Weisburd et al., 2009; LaFree, Dugan, 


\section{PURPOSES AND TARGETS OF POLICING}

\& Korte, 2009). In particular, the determinants of public trust and the antecedents of public willingness to cooperate with police have not been carefully identified.

Early scholarly analyses predicted that the 9/11 attacks would lead to a loosening of constraints on investigative and prosecutorial powers and to a relaxation on legal prohibitions against racial and religious “profiling” (Stuntz, 2002). Subsequent events bear out this analysis. Broad statutory immigration authorities were used in the immediate wake of September 2001 to detain and deport non-citizens from Muslimmajority countries (U.S. Supreme Court, 2009). In November 2001, for example, the U.S. Department of Justice announced a plan to interview 5,000 temporary visa-holders with interviews directed at Arab American concentrations such as southeastern Michigan (Thatcher, 2005). The U.S. Treasury has exercised broad regulatory authority to seize assets based on alleged connections to terrorism and has thereby closed several national Muslim charities (Warde, 2007). Terrorism-related criminal investigations by the Federal Bureau of Investigations and local law enforcement focus disproportionately on mosques and Muslim civic organizations (Kumar, 2010; Temple-Raston, 2007; Huq, 2007). Drawing on the "broken windows" theory of social order maintenance, some highly regarded policing experts have recommended that law enforcement create a more generally “terrorist-unfriendly environment" through surveillance, public-private partnerships, and “intelligence-led policing” (Kelling \& Bratton, 2006). The dominant model of counterterrorism policing in short has emphasized coercion and surveillance over the elicitation of cooperation through trust-building.

However, these tactics have been directed as a particular community, just as minorities have long complained that policing against ordinary crime is disproportionately directed as particular minority communities. Post-9/11 changes to policing strategies have been primarily targeted towards Muslim, South Asian and Arab Americans (Cainkar, 2009; Detroit Arab American Study Team 2009; Huq, 2007). It has been argued that this disparate policing of populations has also been accompanied by the discriminatory treatment of individuals based of race, ethnicity, or perceived religion (Rice \& Parkin, 2010; Nguyen, 2005).

While similar in some ways, public responses to post-9/11 policing strategies may diverge from pre-9/11 efforts at crime control for at least two reasons. First, people may 


\section{PURPOSES AND TARGETS OF POLICING}

respond differently to counterterrorism policing than to crime-control because they view terrorism as imposing a graver risk of harm to individuals than the more diffuse consequences of ordinary crime. Second, people may have different normative assessments of crime and terrorism. Ordinary crime is often motivated by hope of pecuniary gain and is a crime against people. Terrorism is often motivated by strongly held ideologies with either political or religious components and is an act directed against the political and social structure of society. Divergent motives for crime and terrorism may lead to different public tolerances for tough policing countermeasures. No previous study, however, has compared the responses of the same population to crime control and counterterrorism.

Understanding the determinants of public cooperation may be particularly important to the success of counterterrorism efforts. If the police believe that terrorist groups seek to recruit from within ethnic communities, their investigations will face cultural and linguistic barriers that can be considerably mitigated by internal cooperation (Innes 2006). Recent studies of terrorist groups’ dynamics also highlight the significance of public support in counterterrorism success (Blum \& Heymann, 2010; Cronin, 2009; Jones \& Libicki, 2008). These studies suggest that governments defeat terrorist groups most effectively by marginalizing them from existing or hoped-for constituencies from whom terrorist groups seek to gain support (Cronin, 2009). In analyzing the comparative dynamics of public cooperation with police, therefore, this study addresses a question of underappreciated public policy significance.

\section{The effects of targeting suspect groups}

This study also examines the effect of the disparate targeting of particular ethnic or religious minority groups in the population in both the crime-control and the counterterrorism contexts. The unequal allocation of policing attention and sanctions along racial lines is familiar from the criminal law context (Stuntz, 2008; Cole, 2000; Kennedy, 1997). Racial disparities in ordinary crime control arise in the context of economic and demographic changes that disadvantage some ethnic groups, that erect barriers to the legitimate job market, and that are in turn reinforced by the disparate operation of the criminal justice system (Wilson, 2009; Loury, 2003). Even beyond the 


\section{PURPOSES AND TARGETS OF POLICING}

disparate attention drawn by different criminal propensities, minorities often also feel they are the target of unwarranted attention motivated by prejudice. As noted above, Muslim, South Asian, and Arab American populations similarly have received more law enforcement attention than the general population on counterterrorism grounds (Cainkar, 2009; Detroit Arab American Study Team, 2009; Huq, 2007).

The comparative aspect of the study allows analysis of two questions related to the targeting of a minority group. First, it cannot be assumed that the responses of the populations targeted for counterterrorism ends will be the same as those targeted for crime-control ends. Muslim Americans are not typically economically or geographically separated from the general American public like those minorities most affected by crime control measures (Jamal, 2010). Muslim American demographics differ from those of the general population in other ways, for example due to the higher proportion of individuals born overseas (GhaneaBassiri, 2010; Curtis, 2009). A 2007 national survey found only $35 \%$ of U.S. Muslims to be born in the United States; 24\% were born in the Middle East or North Africa and 18\% were born in South Asia; 26\% were found to be black (Pew Research Center, 2007).

It is possible that harassment or disrespect will undermine perceptions of fairness and legitimacy among Muslims (Rice \& Parkin, 2010; Nguyen, 2005). But it is also possible that early experiences with police overseas in nondemocratic contexts with a weak rule of law may yield different expectations of police behavior among Muslims. Further, while the general model of procedural justice is at this point well defined based upon studies of the United States and Europe, research also makes clear that procedural justice effects are not universal. On the contrary, they seem to disappear or diminish in cultures characterized by high power-distance values. In high power distance cultures people do not feel entitled to question or participate in the exercise of authority, which they view as the appropriate role for leaders. Studies conducted in China, for example, suggest that procedural justice effects are not found in work settings (Brockner et al., 2001). While there is no prior research on procedural justice in majority-Muslim societies, such societies may also be examples of high-power distance cultures.

Moreover, members of both the minority and the majority populations may respond in divergent ways to law enforcement if they know law enforcement treats 


\section{PURPOSES AND TARGETS OF POLICING}

individuals differently based on race, ethnicity, or perceived religious affiliation. For the police, both minority and majority group reactions may be important. The target group’s cooperation may be especially important to identifying the sources of crime or terrorism. The legitimacy judgments of the larger, non-targeted majority group, by contrast, are relevant to general social-order maintenance.

Disparate treatment in and of itself may be viewed by both minority and majority populations as reflecting procedural injustice. It would hence undermine police legitimacy judgments in both groups. Past studies find that non-minority groups base judgments of procedural justice on both how their ethnic cohort is treated and on how police treat other racial and ethnic groups (Tyler, 2005; Tyler and Wakslak, 2004). The existence of "spillover effects" from minority community treatment into the views of a majority community in counterterrorism has not previously been investigated. But a recent study conducted in Israel provides some evidence for their existence (Jonathan \& Weisburd, 2010). In this study the Jewish population was found to support the belief that counterterrorism policing hampered the construction of positive relations with Israeli Arabs. The study, however, did not address directly whether Jewish respondents viewed the police as less legitimate if they engaged in unfair tactics when dealing with Arabs.

\section{Summary}

The studies presented address three questions. First, whether the procedural justice model applies across policing functions and policed populations. It is hypothesized the procedural justice will shape legitimacy and cooperation irrespective of variations in context. Second, whether the perception that another group is the target of disproportionate policing efforts has any effect on the cooperation behavior of a nontargeted population. In keeping with the theme that people care about justice it is predicted that when people believe there is injustice in policing it will lower legitimacy and undermine cooperation both when they personally experience such injustice and when they believe that the police treat other people and/or people in other groups unfairly. And third, whether people attend to different aspects of policing behavior if their community is targeted for heightened policing attention. It is hypothesized that, within the context of the United States, procedural justice/legitimacy will generally be 


\section{PURPOSES AND TARGETS OF POLICING}

defined in terms of similar procedural elements by respondents irrespective of context. The four procedural elements shaping procedural justice are predicted to be: voice, neutrality, trust, and treatment with respect.

\section{V. $\quad$ Method}

To understand how policing policies and tactics influence public cooperation with law enforcement this paper analyzes the results of four post-9/11 surveys of the residents of New York City. Two types of sampling were used: random sampling of the population and targeted sampling of the Muslim population. Sampling details are provided in Appendix A.

All four surveys address issues of policing. In the first survey a random sample of 1,653 of the residents of New York City were interviewed about cooperation with the police in efforts to combat ordinary crime. This survey focused upon a comparison of White and minority (i.e., African-American and Hispanic) cooperation (see Tyler \& Fagan, 2008). Its results are here compared to those from three other surveys: a survey of 200 Muslim-Americans living in New York City about cooperation with the police in efforts to combat ordinary crime; a survey of 300 Muslim-Americans living in New York City about cooperation with the police in efforts to combat terrorism; and a sample of 200 non-Muslims living in New York City about cooperation with the police in efforts to combat terrorism. The survey instruments allow the comparison of three groups: Muslim Americans, non-minority (i.e., Caucasian) non-Muslims, and minority (i.e., AfricanAmerican and Hispanic) non-Muslims.

The four surveys were not conducted at the same time. In particular, the random sample of NYC residents that focuses on crime was conducted in 2002-2003. The sample used is the first wave of a two wave panel of respondents and includes. The sample of Muslim NYC residents asked about terrorism was taken in April and May 2009. The samples of Muslim NYC residents asked about crime and non-Muslim NYC residents asked about terrorism were drawn in March and April 2010.

We believe that comparisons across surveys to be reasonable because all four surveys were conducted after September 2001 and because the terror-related surveys were conducted close in time. Further, the analysis here aims to evaluate the psychology 


\section{PURPOSES AND TARGETS OF POLICING}

of public behavior (and hence the relations between observed variables within a sample). The analysis does not aim to estimate or compare the absolute value of public opinion within the population. Questions asked and scales formed are detailed in Appendix B. Scale means and reliabilities are presented in Appendix C.

\section{Results}

This section addresses three issues in turn. The first issue addressed is the psychology underlying public cooperation with efforts to combat ordinary crime: Does it make a different for public cooperation that the police are fighting terrorism rather than crime? We consider separately whether legitimacy effects and procedural justice effects are different in the crime control and counterterrorism contexts. The second issue is spillover effects: Does the perception of disparate treatment of a minority group consistently change the behavior of other minority and majority groups? The third issue concerns the determinants of procedural justice. If procedural justice mechanisms are observed across populations, is there nonetheless variation in the aspects of police behavior to which different populations look?

\section{A. Legitimacy and cooperation}

Ordinary least squares (OLS) regression analysis is used to examine the role of three factors in shaping two kinds of cooperative behavior. The first form of cooperation involves the willingness to work with law enforcement in educating and encouraging other community members in the joint production of public safety. The second involves the willingness to report specific risks to the police.

Three independent variables were considered. These were legitimacy, the effectiveness of the police in addressing crime issues, and the ability of the police to catch and punish rule breakers.

The regression specification also included demographic parameters (age, education, income and gender). In the case of non-Muslims that sample distinguished between White and minority respondents. The larger sample on crime also distinguished between Hispanic and African-American respondents. Muslim sample asked about several background characteristics. Those were: the proportion of the respondent's life 


\section{PURPOSES AND TARGETS OF POLICING}

spend in the US; whether English was spoken in the respondent's home; Muslim identification; and whether the respondent came from either of two distinct regions: South Asia or the Middle East. In each case, the analysis assessed whether these variables had a significant influence on the dependent variables. If so, they were included in the equation.

Table 1 reports coefficients for the surveys on crime control. The results examine the factors shaping whether Muslim and non-Muslim respondents cooperated by alerting the police to crime issues and by cooperating in policing the community. Table 1 shows the results for white respondents $(n=550)$; for non-white respondents $(n=1103)$; and for Muslim respondents $(n=200)$.

\section{[Insert Table 1 here]}

The results shown in Table 1 suggest that legitimacy (the belief that the respondent should defer to legal authorities) was strongly positively correlated with both forms of cooperative behavior for all three groups (Muslim Americans, non-minority non-Muslims, and minority non-Muslims). For all three groups, legitimacy is more strongly related to cooperative behavior than were either estimates of police effectiveness or estimates of deterrence effects (i.e., the likelihood that police catch law breakers). Deterrence effects were observed only for minority non-Muslims; but even for this population, legitimacy provided a more powerful explanation of cooperation.

Similar results are obtained in the case of anti-terror policing. Table 2 reports the results for non-Muslims $(\mathrm{n}=200)$ and Muslims $(\mathrm{n}=300)$ on counterterrorism. Interestingly, none of the Muslim background variables influenced Muslim actions regarding terrorism, while demographics did influence the actions of non-Muslims.

For both groups, beliefs about legitimacy provided a powerful predictor of cooperative behavior. By contrast, the ability of police to induce feelings of safety had no correlation with cooperation within either group. For both Muslim and non-Muslim respondents, instrumental factors were also important, albeit in different ways. In the case of non-Muslims the seriousness of terror mattered as much as legitimacy concerns. With Muslims, judgments about police effectiveness appeared to shape willingness to alert the police.

[Insert Table 2 here] 


\section{PURPOSES AND TARGETS OF POLICING}

\section{B. $\quad$ Procedural justice and legitimacy}

A second part of procedural justice models of policing is the effect of procedural justice considerations on legitimacy. This is addressed for policing against ordinary crime in Table 3 and for terrorism in Table 4.

The findings are strongly supportive of the basic procedural justice model among all the groups studied. For all three populations studied, procedural justice in the implementation phase of policing is a powerful predictor of legitimacy judgments whether it concerns police crime-control or counterterrorism efforts. Previous studies of crime control have emphasized the relevance of how crime control is implemented on the ground. Table 4 shows that both studied populations also respond to the procedures through which policies are adopted.

[Insert Tables 3 and 4 here]

\section{Spillover effects}

The second question focuses on spillover effects. Such effects would reflect concern by non-targeted populations about the actions of the police when dealing with the targeted population. Table 5 reports the effect on procedural justice and legitimacy judgments of beliefs that police engaged in crime control target minorities, act on the basis of racist motives, or harass minorities. The sample is broken into minority and White subgroups.

\section{[Insert Table 5 here]}

The results indicate that White respondents view the police as less fair and less legitimate if they target minorities. The corrosive effect of this belief on majority legitimacy judgments is stronger if White respondents view that behavior as motivated by police prejudice and if White respondents believe that police are harassing minorities.

Can the same spillover effects be observed in counterterrorism policing? Table 6 reports a parallel analysis for the counterterrorism data. Table 7 presents data on whether different kinds of policing tactics have different effects on Muslim and non-Muslim populations.

\section{[Insert Tables 6 and 7 here]}

As Table 6 shows, non-Muslims view the police as unfair and less legitimate if they target the Muslim community and if they treat Muslims disrespectfully. Police 


\section{PURPOSES AND TARGETS OF POLICING}

suspicion of Muslims, interestingly, is not viewed as unfair either among Muslims or non-Muslims respondents. But the data suggest that such suspicions would be damaging if they led to targeting of the Muslim community or harassment of Muslims. Hence, spillover effects from police treatment of minorities are relevant to counterterrorism policing as well as crime control.

The finding of a spillover effect is also supported by an analysis of public and private police actions. "Public" actions are actions such as searching bags at train stations, while "private” actions are actions such as wiretaps or clandestine searches of homes that are not publicized or otherwise visible. An analysis of such police actions is presented in Table 7. This shows that non-Muslims and Muslims have similar beliefs about the frequency and the intrusiveness of policing measures. Both sets of respondents indicated that similar levels of police intrusions were occurring. Both groups also linked public intrusions to unfairness and lower legitimacy. Neither group, however, viewed police intrusions that did not happen in public as undermining fairness or legitimacy.

These findings suggest that Muslims and non-Muslims have similar views about the frequency and intrusiveness of policing tactics. In this respect terrorism differs from crime since studies suggest that minority group members are more likely to believe that the police "racially profile” minorities (Tyler \& Wakslak, 2004). However, as noted, even in the case of crime, White respondents view profiling of minorities as unfair and, when they believe it occurs, view the police as less legitimate. This implies that spillover effects are likely to be more significant, all other things being equal, in the terrorism context, where non-minority beliefs of the frequency of profiling correlate with the beliefs of the minority.

\section{The psychology of procedural justice}

Finally, factors shaping judgments of procedural justice and legitimacy are considered. Since procedural justice and legitimacy were found to interrelate, the analysis uses a combined measure of procedural justice and legitimacy. Four procedural elements are considered as independent variables: voice; neutrality; trust, and respect. The results are shown in Table 8.

[Insert Table 8 here] 


\section{PURPOSES AND TARGETS OF POLICING}

These results broadly suggest that three elements of procedure: neutrality; trust; and treatment with respect were generally found to shape evaluations of the police. They also allow for comparisons between targeted groups and non-targeted groups, and thereby enable an assessment of whether being targeted by police changes the way in which a population judges police behavior. It also enables an assessment of whether being targeted for crime control has different effects from being targeted for counterterrorism ends.

For both the targeted group in crime control (African American minorities) and the targeted group for counterterrorism (Muslims), neutrality was the most important factor shaping police evaluations; respect was second; and trust was third. For nontargeted groups, the results were less clear. Muslims evaluating anti-crime policing focused on respect, as did non-Muslims considering anti-terror policing. On the other hand, Whites evaluating anti-crime policing focused upon neutrality. Overall, there is no evidence that targeted groups systematically differ from non-targeted groups, i.e., that being targeted changes the aspects of police behavior to which people attend in making procedural justice and legitimacy judgments.

Does it matter if the respondent is a Muslim? A comparison of Muslims to nonMuslims (Whites; Hispanics; African-Americans) suggests that this is not a useful categorization. Neither Muslims nor non-Muslims are wholly consistent in selecting grounds on which to evaluate the police. In the case of anti-terror policing Muslims focus on neutrality; regarding crime, they focus on respect. Non-Muslims focus on respect in the case of anti-terror policing, but Whites focus on neutrality with crime, while minorities focus on neutrality. Again, overall, there is no clear suggestion that Muslims and non-Muslims differ systematically in the way they evaluate the police. Further among the non-Muslim group Whites and minorities also differ. The overall point is that there do not appear to be any major or systematic differences between Muslims; White non-Muslims; and minority non-Muslims. 


\section{PURPOSES AND TARGETS OF POLICING}

\section{Discussion}

This paper addresses three issues: whether the procedural justice model can be generalized to new populations within the U.S. and new policing functions; the sensitivity of non-targeted groups to actions taken toward others; and the aspects of police behavior that correlate to judgments about procedural justice in different populations and across different policing issues.

\section{A. Generalizing the procedural justice model beyond crime control}

The data presented in this study was drawn from four surveys of diverse populations affected in different ways by old and new policing functions. The data involved a new, minority population that has not been studied before. It addressed a post9/11 policing function that has not been well understood. Despite these differences, both aspects of the procedural justice mechanism that have been identified in past studies were found to operate in all of the four studies. Indeed, there is no evidence that procedural justice mechanisms are diminished by a perception of greater risk in the terrorism context.

Rather, the shift in policing function from crime control to counterterrorism does not appear to have changed public expectations of police behavior or to have altered the basis on which police are evaluated when people make judgments about cooperation. Within both the crime control and the counterterrorism contexts, moreover, being targeted for heightened policing attention does not significantly change how individuals assess the police. Both those who are the primary target of policing and those who are not a primary target apply a shared framework in reacting to police actions.

Finally, the fact that Muslims Americans have different religious and cultural values, and may have had different formative interactions with law enforcement overseas, does not impinge on the predictive power of the procedural justice model. At least within the United States, therefore, procedural justice mechanisms provide a powerful and transubstantive explanation for public cooperation with law enforcement across diverse populations and policing functions.

This framework is normative and not instrumental. It rests on judgments of the procedural justice of the police and connected beliefs about the legitimacy of law enforcement institutions. The first element of the procedural justice model is the role of 


\section{PURPOSES AND TARGETS OF POLICING}

legitimacy in predicting cooperation. The results of this study suggest that although some instrumental factors play some role in public judgments about policing, legitimacy always emerges as either the only issue or one of the more important influences shaping cooperation. The second part of the procedural justice framework is the connection between procedural justice and legitimacy. Here the results strongly and consistently point to procedural justice as a core factor shaping both legitimacy and cooperation among the members of all groups and over both issues. In the case of crime, procedural justice is the primary influence upon legitimacy and cooperation across groups. With terrorism similar results are obtained.

These findings are consistent with earlier examinations of the policing of MuslimAmericans. For crime and non-Muslims they are similar to the analysis of policing data by Tyler \& Fagan (2008) based upon a subset of the crime respondents examined here who had completed a second round of interviews $(n=803)$, and with the results of another study of New Yorkers based upon responses to the wave one sample used in this paper (Sunshine \& Tyler, 2003). For Muslims and policing against terror the results are similar to those of Tyler, Schulhofer \& Huq (2010).

Within the common framework that emerges from the data, there are also distinctions meriting attention. In the case of both ordinary crime and terrorism, MuslimAmericans are the least instrumental. With ordinary crime, their cooperation is not influenced by either evaluations of police effectiveness or their ability to catch those who break the law. Among Whites and minorities, effectiveness in managing crime shapes willingness to alert the police, and among minorities the ability to catch those who break the law shapes both forms of cooperation. With respect to terrorism, Muslims' willingness to alert the police is influenced by evaluations of police effectiveness in stopping terror attacks, while all forms of non-Muslim cooperation with efforts to manage terrorism are shaped by the estimated seriousness of the terror threat.

In sum, even though terrorism is generally perceived as presenting greater potential harms than ordinary crime (Stuntz, 2002), that perception does not appear to dilute or mitigate expectations of procedural justice: Even when police confront grave threats, both minority and majority populations expect law enforcement officers to respect procedural justice values, and are more likely to withhold their cooperation if they 


\section{PURPOSES AND TARGETS OF POLICING}

do not. It is especially striking in this respect that non-Muslims, who rate the threat of terror as larger than do Muslims, are nonetheless sensitive to procedural justice in counterterrorism policing, particularly the targeting and harassment of Muslims.

\section{B. The pervasiveness of spillover effects}

Societies facing internal or external threats to social order often adopt harsh tactics toward internal or external minorities viewed as linked to those threats. American history contains no shortage of examples of ethnic groups (e.g., Japanese Americans in World War II, European migrants after World War I) and political groupings (e.g., Communists in the Cold War) being targeted for criminal sanctions or other forms of suppression in crisis moments (Stone 2004). One inference from this history might be that perceptions of grave risk dilute the attention people devote to the fair treatment of others.

The study finds support for the claim that people do attend to the abuse of other groups' rights in both ordinary times and also when faced with unusually grave threats. In the context of ordinary crime, members of majority groups that are not targeted for heightened policing nonetheless respond to perceived discrimination against minorities by evincing less willingness to cooperate with police. This spillover effect, previously observed with respect to ordinary crime control (Tyler \& Wakslak, 2004), is also observed in the counterterrorism context. This suggests that the police lose legitimacy in the larger community when they engage in unfair tactics directed at one subgroup but generally viewed as being unfair by the entire population.

Moreover, the findings suggest that Muslim and non-Muslim respondents perceive and evaluate the frequency of police counterterrorism intrusions in similar terms. Spillover effects are thus not attributable to different assessments of the frequency or effects of policing measures. While non-Muslims are less likely to be targeted for such terrorism efforts, both groups react negatively to public police intrusions by lowering their assessments of police procedural justice and legitimacy. Both groups react most strongly to public intrusions, and less strongly to private intrusions.

Interestingly, the non-Muslim respondents in the study distinguished between heightened police suspicion on the one hand, and discriminatory actions or harassment on the other hand. Thus, a majority population belief that police view Muslims as a more 


\section{PURPOSES AND TARGETS OF POLICING}

risky group does not create spillover effects, but a majority population belief that police harass or discriminate does. One way to interpret this finding is as evidence that the the non-Muslim majority believes that the value of providing equal treatment to religious minorities is greater than the value of using perceived statistical regularities (i.e. the belief that Muslims are more likely to be involved in or know about terror activities) in policing efforts. The U.S. Department of Justice's guidelines on racial profiling reflect a similar view in the case of ordinary crime. These Guidelines reject profiling in ordinary crime control on the basis of "statistical evidence of differential rates of commission of certain offenses among particular races” (U.S. Department of Justice, 2003).

How do these findings fit alongside the well-known history of disproportionate targeting of minorities in times of crisis? One hypothesis is that even though public support for profiling and disproportionate attention to minorities may rise in times of heightened threat, people nevertheless remain aware that the tactics that police adopt in response are unfair and respond negatively to police that accede to popular pressures to profile, discriminate, and harass. That is, this data suggests that the public remains aware of the unfairness of certain policing methods even when demand for such measures is perceived to rise.

\section{Procedural elements shaping evaluations of procedural justice and legitimacy.}

Prior studies suggest that White and minority respondents in the United States generally have similar models for defining procedural justice in the context of ordinary crime (Tyler 2005). This analysis extends this prior effort in two ways: by considering Muslim-Americans and by examining reactions to policing against terrorism. Despite this extension, the results are similar in suggesting that three elements of procedural justice neutrality in decision making, trust in the motives of the police, and treatment with respect -- remain central to the definition of procedural justice and its effect on legitimacy. This result holds in both the crime control and the counterterrorism contexts. Neither the kind of violent threat nor the identity of the respondents changes the basic behavioral predicates of procedural justice.

This finding is cause for optimism. It suggests policing strategy and tactics can be generalized and do not need to be tailored to a particular population or task. That result is consistent with earlier studies of crime control based upon a study of police-citizen 


\section{PURPOSES AND TARGETS OF POLICING}

encounters in Oakland and Los Angeles (Tyler \& Huo, 2002). Further, the outlines of that general strategy are also clear from previous research (see Schulhofer, Tyler \& Huq, 2011, for a discussion of general implications for policing). This research suggests that police training and organization can usefully incorporate benchmarks and practices of procedural justice as a means to more successful order-maintenance.

\section{Conclusion}

Procedural justice mechanisms provide a robust and broadly applicable framework for predicting public cooperation with law enforcement. Rather than attempting to impress the public with the seriousness of a threat, or showing responsiveness by channeling resources toward minority groups, police better secure public cooperation by behaving with procedural justice toward all groups. This is the case, counterintuitively, for both the minority group being targeted and also for the nontargeted majority. Neutrality, trust and respect should play central roles in the policing function regardless of whether the police are dealing with everyday crime or with terrorism. 
Becker, G.S. (1976). The economic approach to human behavior. Chicago, IL: University of Chicago Press.

Bjelopera, J.P., \& Randol, M.A. (2010). American jihadist terrorism: Combating a complex threat. Washington, DC: Congressional Research Service.

Blum, G., \& Heymann, P.B. (2010). Laws, outlaws, and terrorists: Lessons from the War on Terrorism. Cambridge, MA: MIT Press.

Brockner et al. (2001). Culture and procedural justice: The influence of power distance on reactions to voice. Journal of Experimental Social Psychology, 37(4), 300-315. doi:10.1006/jesp.2000.1451

Cainkar, L.A. (2009). Homeland insecurity: The Arab American and Muslim American experience after 9/11. New York, NY: Russell Sage Foundation.

Cashin, S. (2010). To be Muslim or "Muslim-looking" in America: A comparative exploration of racial and religious prejudice in the $21^{\text {st }}$ century. Duke Forum for Law \& Social Change, 2, 125-139. Retrieved from http://www.law.duke.edu/journals/dflsc/

Clarke, P. (2007). Learning from experience: Counter terrorism in the UK since 9/11. London, England: Policy Exchange.

Cole, D. (1999). No equal justice: Race and class in the American criminal justice system. New York, NY: New Press.

Cronin, A.K. (2009). How terrorism ends: Understanding the decline and demise of terrorist campaigns. Princeton, NJ: Princeton University Press.

Curtis, E.E. (2009). Muslims in America: A short history. New York, NY: Oxford University Press.

Detroit Arab American Study Team (2009). Citizenship and crisis: Arab Detroit after 9/11. New York, NY: Russell Sage Foundation.

Ghanea Bassiri, K. (2010). A History of Islam in America: From the New World to the new world order. New York, NY: Cambridge University Press.

Gottschalk, P., \& Greenberg, G. (2008). Islamophobia: Making Muslims the enemy. Lanham, MD: Rowman \& Littlefield.

Huq, A. (2007). The new counterterrorism: Investigating terrorism, investigating Muslims. In R.C. Leone \& G. Anrig, Jr. (Eds.), Liberty under attack: Reclaiming our freedoms in a time of terror (pp. 167-188). New York, NY: PublicAffairs.

Huq, A.Z., Tyler, T.R., \& Schulhofer S.J. (2011). Mechanisms for eliciting cooperation in counterterrorism policing. Unpublished manuscript.

Innes, M. (2006). Policing uncertainty: Countering terror through community intelligence and democratic policing. Annals of the American Academy of Political and Social Sciences, 605, 222-241. doi:10.1177/0002716206287118

Jamal, A. (2010). Muslim Americans: Enriching or depleting American democracy? In A. Wolfe \& I. Katznelson (Eds.), Religion and democracy in the United States: Danger or opportunity? (pp. 89-113). Princeton, NJ: Princeton University Press.

Jonathan, T., \& Weisburd, D. (2010). How do majority communities view the potential costs of policing terrorism? Findings from a community survey in Israel. Policing, 4, 169-181. doi:10.1093/police/paq004

Jones, S.G., \& Libicki, M.C. (2008). How terrorist groups end: Lessons for countering Al-Qa'ida. Santa Monica, CA: The RAND Corporation. 


\section{PURPOSES AND TARGETS OF POLICING}

Kelling, G.L., \& Bratton, W.J. (2006). Policing terrorism. New York, NY: Manhattan Institute.

Kennedy, R. (1998). Race, crime and the law. New York, NY: Vintage.

Kumar, A. (2010). A foreigner carrying in the crook of his arm a tiny bomb. Durham, NC: Duke University Press.

LaFree, G., Dugan, L., \& Korte, R. (2009). The impact of British counterterrorist strategies on political violence in Northern Ireland: Comparing deterrence and backlash models. Criminology, 47, 17-45. doi:10.1111/j.1745-9125.2009.00138.x

Lee, S., Gibbons, J., Thompson, J., \& Timani, H. (2009). The Islamophobia scale: Instrument development and initial validation. International Journal for the Psychology of Religion, 19(2), 92-105. doi: 10.1080/10508610802711137

Loury, G. (2003). The anatomy of racial inequality. Cambridge, MA: Harvard University Press.

Love, E. (2009). Confronting Islamophobia in the United States: Framing civil rights activism among Middle Eastern Americans. Patterns of Prejudice, 43(3/4), 401425. doi:10.1080/00313220903109367

Nguyen, T. (2005). We are all suspects now: Untold stories from immigrant communities after 9/11. Boston, MA: Beacon Press.

Pew Research Center (2007). Muslim Americans: Middle class and mostly mainstream. Washington, DC.

Rice, S.K., \& Parkin, W.S. (2010). New avenues for profiling and bias research: The question of Muslim Americans. In S.K. Rice \& M.D. White (Eds.), Race, ethnicity, and policing: New and essential readings (pp. 450-467). New York, NY: NYU Press.

Schulhofer, S.J., Tyler, T.R., \& Huq, A.Z. (forthcoming 2011). American Policing at a Crossroads: Unsustainable policies and the procedural justice alternative. Journal of Criminal Law and Criminology.

Stone, G.R. (2004). Perilous times: free speech in wartime from the Sedition Act of 1798 to the War on Terrorism. New York, NY: W.W. Norton \& Company.

Stuntz, W.J. (2002). Local policing after the terror. Yale Law Journal, 111(8), 2137-2194. doi:10.2307/797644

Stuntz, W.J. (2008). Unequal justice. Harvard Law Review, 121(8), 1969-2040. Retrieved from http://www.harvardlawreview.org/index.php

Sunshine, J., \& Tyler, T.R. (2003). The role of procedural justice and legitimacy in shaping public support for policing. Law and Society Review, 37(3), 555-589. doi:10.1111/1540-5893.3703002

Temple-Raston, D. (2007). The jihad next door: The Lackawanna Six and rough justice in an age of terror. New York, NY: PublicAffairs.

Thatcher, D. (2005). The local role in homeland security. Law and Society Review, 39(3), 635-676. doi: 10.1111/j.1540-5893.2005.00236.x

Tyler, T.R. (1988). What is procedural justice?: Criteria used by citizens to assess the fairness of legal procedures. Law and Society Review, 22, 103-136. doi:10.2307/3053563

Tyler, T.R. (1994). Governing amid diversity: Can fair decision-making procedures bridge competing public interests and values? Law and Society Review, 28, 701722. Retrieved from http://www.lawandsociety.org/review.htm 


\section{PURPOSES AND TARGETS OF POLICING}

Tyler, T.R. (2000). Multiculturalism and the willingness of citizens to defer to law and to legal authorities. Law and Social Inquiry, 25(4), 983-1019. doi:10.1111/j.17474469.2000.tb00314.x

Tyler, T.R. (2001). Public trust and confidence in legal authorities: What do majority and minority group members want from the law and legal authorities? Behavioral Science and the Law, 19(2), 215-235. doi:10.1002/bsl.438

Tyler, T.R. (2004). Enhancing police legitimacy. Annals of the American Academy of Political and Social Science, 593, 84-99. doi:10.1177/0002716203262627

Tyler, T.R. (2005). Policing in black and white: Ethnic group differences in trust and confidence in the police. Police Quarterly, 8(3), 322-342. doi:10.1177/1098611104271105

Tyler, T.R. (2006a). Psychological perspectives on legitimacy and legitimation. Annual $\begin{array}{llll}\text { Review of } & \text { Psychology, }\end{array}$ doi:10.1146/annurev.psych.57.102904.190038

Tyler, T.R. (2006b). Why people obey the law. Princeton, NJ: Princeton University Press.

Tyler, T.R. (2007). Psychology and the design of legal institutions. Nijmegen, the Netherlands: Wolf Legal Publishers.

Tyler, T.R. (2009). Legitimacy and criminal justice: The benefits of self-regulation. Ohio State Journal of Criminal Law, 7, 307-359. Retrieved from http://moritzlaw.osu.edu/osjcl/

Tyler, T.R., \& Fagan, J. (2008). Why do people cooperate with the police? Ohio State Journal of Criminal Law, 6, 231-275. Retrieved from http://moritzlaw.osu.edu/osjcl/

Tyler, T.R., \& Huo, Y.J. (2002). Trust in the law: Encouraging public cooperation with the police and courts. New York, NY: Russell-Sage Foundation.

Tyler, T.R., Schulhofer, S., \& Huq, A.Z. (2010). Legitimacy and deterrence effects in counterterrorism policing: A study of Muslim Americans. Law and Society Review, 44(2), 365-401. doi:10.1111/j.1540-5893.2010.00405.x

Tyler, T.R., \& Wakslak, C. (2004). Profiling and police legitimacy: Procedural justice, attributions of motive, and acceptance of police authority. Criminology, 42(2), 253-282. doi:10.1111/j.1745-9125.2004.tb00520.x

United States Department of Justice. (2003). Guidance regarding the use of race by federal law enforcement agencies. Washington, DC.

United States Supreme Court. (2009). Ashcroft v. Iqbal, 129 S. Ct. 1937.

Warde, I. (2007). The price of fear: The truth behind the financial war on terror. Berkeley, CA: University of California Press.

Weisburd, D., Feucht, T., Hakimi, I., Mock, L., \& Perry, S. (Eds.). (2009). To protect and serve: Policing in an age of terrorism. New York, NY: Springer.

Wilson, W.J. (2009). More than just race: Being black and poor in the inner city. New York, NY: W.W. Norton \& Company. 
PURPOSES AND TARGETS OF POLICING

Table 1. Why do community residents cooperate with the police to combat ordinary crime?

\begin{tabular}{|c|c|c|c|c|c|c|}
\hline & \multicolumn{2}{|c|}{$\begin{array}{l}\text { Muslims } \\
(\mathrm{n}=200)\end{array}$} & \multicolumn{2}{|c|}{$\begin{array}{l}\text { White non-Muslims } \\
\qquad(\mathrm{n}=550)\end{array}$} & \multicolumn{2}{|c|}{$\begin{array}{c}\text { Minority } \\
\text { non-Muslims } \\
(\mathrm{n}=1103)\end{array}$} \\
\hline & $\begin{array}{l}\text { Alert } \\
\text { Police }\end{array}$ & Cooperate\# & $\begin{array}{l}\text { Alert } \\
\text { Police }\end{array}$ & Cooperate & $\begin{array}{l}\text { Alert } \\
\text { Police }\end{array}$ & Cooperate \\
\hline Legitimacy & $.18^{*}$ & $.23 * *$ & $.30 * * *$ & $.13 *$ & $.29 * * *$ & $.23 * * *$ \\
\hline Effectiveness & $.16^{*}$ & .01 & .08 & -.02 & .07 & .04 \\
\hline Deterrence & .02 & .06 & .01 & $.10^{*}$ & $.14 * * *$ & $.09 * *$ \\
\hline Time in US & .07 & --- & $\begin{array}{ll}-- \\
\end{array}$ & --- & --- & --- \\
\hline $\begin{array}{l}\text { English in } \\
\text { home }\end{array}$ & .16 & --- & --- & --- & --- & --- \\
\hline Muslim ID & -.11 & --- & --- & --- & --- & --- \\
\hline South Asia & .11 & --- & --- & --- & --- & --- \\
\hline Middle East & -.13 & --- & --- & --- & --- & --- \\
\hline Age & .05 & --- & $.18^{* * *}$ & .03 & $.13 * * *$ & .02 \\
\hline Education & .02 & --- & -.11 & -.05 & .08 & .06 \\
\hline Income & $.16^{*}$ & --- & $.30 * * *$ & .01 & $.19 * * *$ & .01 \\
\hline Gender & .00 & --- & .02 & $-.08 *$ & -.01 & -.03 \\
\hline AA/Hispanic & --- & $\begin{array}{l}-- \\
\end{array}$ & $\begin{array}{l}-- \\
\end{array}$ & --- & $-.09 * *$ & $-.08 * *$ \\
\hline Adj. R.-sq. & $14 \% * * *$ & $6 \%$ & $8 \%$ & $4 \%$ & $21 \%$ & $8 \%$ \\
\hline
\end{tabular}

\#The Muslim attribute variables and demographics were not found to significantly influence this dependent variable.

Entries are the adjusted regression coefficient (beta).

${ }^{*} \mathrm{p}<.05, * * \mathrm{p}<.01 ; * * * \mathrm{p}<.001$. 
PURPOSES AND TARGETS OF POLICING

Table 2. Legitimacy and cooperation in combating terrorism.

\begin{tabular}{|c|c|c|c|c|}
\hline & \multicolumn{2}{|c|}{$\begin{array}{l}\text { Non-Muslims } \\
\quad(\mathbf{n}=200)\end{array}$} & \multicolumn{2}{|c|}{$\begin{array}{l}\text { Muslims } \\
(n=300)\end{array}$} \\
\hline & Cooperation & Alert & Cooperation\# & Alert\# \\
\hline Legitimacy & $.22 * *$ & $.27 * * *$ & $0.18^{* *}$ & $0.16 * *$ \\
\hline Police - feel safe & .09 & -.03 & 0.05 & 0.12 \\
\hline Police - effective & .04 & .02 & 0.10 & $0.19 * *$ \\
\hline Terror threat serious & $.13^{* *}$ & $.25 * * *$ & 0.01 & 0.08 \\
\hline Time in US & --- & --- & $\begin{array}{ll}-- \\
\end{array}$ & --- \\
\hline English in home & --- & --- & --- & --- \\
\hline Muslim ID & --- & --- & --- & --- \\
\hline South Asia & --- & --- & --- & --- \\
\hline Middle East & $\begin{array}{ll}-- \\
\end{array}$ & $\begin{array}{ll}--- \\
\end{array}$ & --- & --- \\
\hline Age & .00 & $.14 * *$ & --- & --- \\
\hline Education & -.04 & .04 & --- & --- \\
\hline Income & -.01 & -.08 & --- & --- \\
\hline Gender & -.09 & -.06 & --- & --- \\
\hline Race & $-.24 * *$ & -.16 & $\begin{array}{ll}-- \\
--\end{array}$ & $\begin{array}{ll}-- \\
--\end{array}$ \\
\hline Adj. R.-sq. & $13 \%$ & $14 \%$ & $5 \%$ & $11 \%$ \\
\hline
\end{tabular}

\#The Muslim attribute variables and demographics were not found to influence these dependent variables.

Note. Non-Muslims includes all respondents, White and minority.

Entries are the adjusted regression coefficient (beta). ${ }^{*} \mathrm{p}<.05$, ${ }^{* *} \mathrm{p}<.01 ;{ }^{* * *} \mathrm{p}<.001$. 
PURPOSES AND TARGETS OF POLICING

Table 3. The influence of procedural justice on legitimacy and cooperation in policing against ordinary crime.

\begin{tabular}{|c|c|c|c|c|c|c|}
\hline & \multicolumn{2}{|c|}{$\begin{array}{l}\text { Muslims } \\
(\mathrm{n}=200)\end{array}$} & \multicolumn{2}{|c|}{$\begin{array}{l}\text { Non-Muslim minority (n } \\
=1103 \text { ) }\end{array}$} & \multicolumn{2}{|c|}{$\begin{array}{l}\text { Non-Muslim White } \\
\qquad(\mathrm{n}=550)\end{array}$} \\
\hline & $\begin{array}{c}\text { Legitimacy } \\
\text { \# } \\
\end{array}$ & $\begin{array}{c}\text { Overall } \\
\text { cooperation\# }\end{array}$ & Legitimacy & $\begin{array}{c}\text { Overall } \\
\text { cooperation }\end{array}$ & $\begin{array}{c}\text { Legitimacy } \\
\text { \#\# } \\
\end{array}$ & $\begin{array}{c}\text { Overall } \\
\text { cooperation }\end{array}$ \\
\hline $\begin{array}{l}\text { Procedural } \\
\text { justice- } \\
\text { formation }\end{array}$ & $.18 * * *$ & $0.42 *$ & --- & --- & --- & --- \\
\hline $\begin{array}{l}\text { Procedural } \\
\text { justice- } \\
\text { implementation }\end{array}$ & $.42 * * *$ & 0.10 & $.63 * * *$ & $.25 * * *$ & $.77 * * *$ & $.26 * * *$ \\
\hline Effectiveness & .03 & 0.23 & $.10^{* *}$ & .05 & -.03 & .04 \\
\hline Deterrence & .01 & 0.01 & $.08 * *$ & $.16^{* * *}$ & .07 & .07 \\
\hline Time in US & --- & --- & --- & --- & $\begin{array}{ll}-- \\
\end{array}$ & --- \\
\hline $\begin{array}{l}\text { English in } \\
\text { home? }\end{array}$ & --- & --- & --- & --- & --- & --- \\
\hline Muslim ID & --- & --- & --- & --- & --- & --- \\
\hline South Asia & --- & --- & --- & --- & --- & --- \\
\hline Middle East & $\begin{array}{ll}-- \\
\end{array}$ & --- & --- & --- & --- & $\begin{array}{l}-- \\
-\end{array}$ \\
\hline Age & --- & --- & .04 & $.13 * * *$ & --- & $.14^{* *}$ \\
\hline Education & --- & --- & $-.10^{* * *}$ & $.09 * *$ & --- & $.11^{*}$ \\
\hline Income & --- & --- & -.03 & $.10^{*}$ & --- & $.19 * * *$ \\
\hline Gender & --- & --- & $.07 *$ & .02 & --- & .01 \\
\hline AA/Hispanic & --- & $\begin{array}{ll}-- \\
\end{array}$ & $-.11 * * *$ & $-.08 * *$ & $\begin{array}{ll}-- \\
\end{array}$ & $\begin{array}{ll}-- \\
\end{array}$ \\
\hline Adj. R.-sq. & $29 \%$ & $34 \%$ & $31 \%$ & $11 \%$ & $60 \%$ & $16 \%$ \\
\hline
\end{tabular}

\#The Muslim attribute variables and demographics were not found to significantly influence these dependent variables.

\#\#No significant influence of demographics found.

Entries are the adjusted regression coefficient (beta).

${ }^{*} \mathrm{p}<.05,{ }^{* *} \mathrm{p}<.01 ; * * * \mathrm{p}<.001$. 
PURPOSES AND TARGETS OF POLICING

Table 4. The influence of procedural justice on legitimacy in policing against terrorism.

\begin{tabular}{|l|l|l|l|l|}
\hline & \multicolumn{2}{|c|}{ Non-Muslims (n = 200) } & \multicolumn{2}{c|}{ Muslims (n = 300) } \\
\hline & Legitimacy\# & $\begin{array}{c}\text { Overall } \\
\text { cooperation\# }\end{array}$ & Legitimacy & $\begin{array}{c}\text { Overall } \\
\text { cooperation }\end{array}$ \\
\hline PJ-formation & $0.24^{* * *}$ & $.21^{* *}$ & $0.18^{* * *}$ & $.17^{* *}$ \\
\hline PJ-implementation & $0.38^{* * *}$ & $.18^{*}$ & $0.38^{* * *}$ & $.19^{* *}$ \\
\hline Police - feel safe & $0.21^{* *}$ & .01 & .07 & .02 \\
\hline Police - effective & 0.02 & .01 & .04 & $.21^{* * *}$ \\
\hline Terror threat serious & 0.07 & $.24 * * *$ & $.12^{*}$ & .11 \\
\hline Time in the US & --- & --- & $-.16^{* *}$ & .03 \\
\hline Muslim ID & --- & --- & .03 & .04 \\
\hline English in home? & --- & --- & $-.10^{*}$ & .01 \\
\hline South Asia & --- & --- & .11 & .06 \\
\hline Middle East & --- & --- & .02 & -.06 \\
\hline Age & --- & --- & .08 & -.10 \\
\hline Education & --- & --- & .00 & .11 \\
\hline Income & --- & --- & -.10 & .01 \\
\hline Gender & --- & --- & -.04 & $-.13^{*}$ \\
\hline Race & --- & --- & --- & --- \\
\hline Adj. R.-sq. & $39 \%$ & $14 \%$ & $32 \%$ & $20 \%$ \\
\hline
\end{tabular}

\#Demographics did not significantly influence these variables.

Entries are the adjusted regression coefficient (beta). ${ }^{*} \mathrm{p}<.05,{ }^{* *} \mathrm{p}<.01 ;{ }^{* * *} \mathrm{p}<.001$. 
PURPOSES AND TARGETS OF POLICING

Table 5. Do White respondents care how the police treat minorities when policing against crime?

\begin{tabular}{|l|l|l|l|l|}
\hline & \multicolumn{2}{|c|}{$\begin{array}{c}\text { Non-Muslim minorities } \\
(\mathrm{n}=1003)\end{array}$} & \multicolumn{2}{c|}{$\begin{array}{c}\text { Non-Muslim White } \\
(\mathrm{n}=550)\end{array}$} \\
\hline & $\begin{array}{c}\text { Procedural } \\
\text { justice\# }\end{array}$ & Legitimacy & $\begin{array}{c}\text { Procedural } \\
\text { justice }\end{array}$ & Legitimacy\# \\
\hline Police target minorities & $-.06^{*}$ & $-.13^{* * *}$ & -.08 & $-.14^{* * *}$ \\
\hline $\begin{array}{l}\text { Police target minorities } \\
\text { because of racism }\end{array}$ & -.05 & $-.15^{* * *}$ & $-.15^{* * *}$ & $-.31^{* * *}$ \\
\hline Harass minorities & $-.37^{* * *}$ & $-.21^{* * *}$ & $-.24^{* * *}$ & $-.21^{* * *}$ \\
\hline Age & --- & $.11^{* * *}$ & $.09^{*}$ & --- \\
\hline Gender & --- & $.13^{* * *}$ & .00 & --- \\
\hline Income & --- & -.01 & $.14^{* * *}$ & --- \\
\hline Education & --- & -.06 & -.02 & --- \\
\hline AA/Hispanic & --- & $-.08^{* * *}$ & -- & -- \\
\hline Adj. R.-sq. & $18 \%$ & $15 \%$ & $14 \%$ & $21 \%$ \\
\hline
\end{tabular}

\#No significant demographic influences were found.

Entries are the adjusted regression coefficient (beta). ${ }^{*} \mathrm{p}<.05,{ }^{* *} \mathrm{p}<.01 ;{ }^{* * *} \mathrm{p}<.001$. 
PURPOSES AND TARGETS OF POLICING

Table 6. Do non-Muslims care how the police treat Muslims in counter-terror policing?

\begin{tabular}{|l|l|l|l|l|}
\hline & \multicolumn{2}{|c|}{ Procedural justice\# } & \multicolumn{2}{c|}{ Legitimacy\# } \\
\hline Police are suspicious of Muslims & -.05 & --- & -.07 & --- \\
\hline Police treat Muslims disrespectfully & $-.17^{*}$ & --- & $-.24^{* *}$ & ---- \\
\hline $\begin{array}{l}\text { Police increasingly targeting Muslim } \\
\text { community. }\end{array}$ & & $-.18^{*}$ & --- & $-.17^{*}$ \\
\hline Police - feel safe & $.30^{* * *}$ & $.38^{* * *}$ & $.32^{* * *}$ & $.36^{* * *}$ \\
\hline Police - effective & $.26^{* * *}$ & 0.13 & 0.12 & 0.10 \\
\hline Terror threat real & 0.04 & 0.12 & 0.11 & 0.11 \\
\hline Age & --- & --- & --- & --- \\
\hline Education & --- & --- & --- & ---- \\
\hline Income & --- & --- & --- & ---- \\
\hline Gender & --- & --- & --- & --- \\
\hline Race & --- & --- & --- & --- \\
\hline Adj. R.-sq. & $27 \%$ & $23 \%$ & $26 \%$ & $27 \%$ \\
\hline
\end{tabular}

\#Demographic variables did not significantly influence either dependent variable.

Entries are the adjusted regression coefficient (beta). ${ }^{*} \mathrm{p}<.05$, ${ }^{* *} \mathrm{p}<.01$; ${ }^{* * *} \mathrm{p}<.001$.

Note. This is a sample of White and minority non-Muslims. 
PURPOSES AND TARGETS OF POLICING

Table 7. Reactions to anti-terror police intrusions into the community among Muslims and non-Muslims.

\begin{tabular}{|l|l|l|l|l|l|l|}
\hline & \multicolumn{2}{|c|}{ Average levels } & \multicolumn{2}{c|}{ Procedural justice } & \multicolumn{2}{c|}{ Legitimacy } \\
\hline & Muslim & $\begin{array}{c}\text { Non- } \\
\text { Muslim }\end{array}$ & Muslims & $\begin{array}{c}\text { Non- } \\
\text { Muslims }\end{array}$ & Muslims & $\begin{array}{c}\text { Non- } \\
\text { Muslims }\end{array}$ \\
\hline $\begin{array}{l}\text { Public police } \\
\text { intrusions }\end{array}$ & $\begin{array}{l}2.36 \\
(0.78)\end{array}$ & $\begin{array}{l}2.32 \\
(0.68)\end{array}$ & $-.28 * * *$ & $-.29 * * *$ & $-.29 * * *$ & $-.16^{*}$ \\
\hline $\begin{array}{l}\text { Private police } \\
\text { intrusions }\end{array}$ & $\begin{array}{l}2.37 \\
(1.02)\end{array}$ & $\begin{array}{l}2.33 \\
(0.93)\end{array}$ & -.12 & .03 & -.09 & -.15 \\
\hline Years in US & --- & --- & .05 & --- & .12 & --- \\
\hline $\begin{array}{l}\text { English in } \\
\text { home? }\end{array}$ & --- & --- & -.16 & --- & -.11 & --- \\
\hline Muslim ID & --- & --- & -.04 & --- & -.02 & --- \\
\hline South Asia & --- & --- & .04 & --- & .12 & --- \\
\hline Middle east & --- & --- & .03 & --- & -.13 & --- \\
\hline Age & --- & --- & -.04 & .13 & -.20 & $.16^{*}$ \\
\hline Gender & --- & --- & .07 & .02 & .06 & -.01 \\
\hline Education & --- & --- & -.02 & -.13 & -.02 & $-.22^{*}$ \\
\hline Income & --- & --- & .07 & .18 & $-.21 *$ & .08 \\
\hline Race & --- & --- & --- & $-.22 *$ & --- & -.12 \\
\hline Adj. R.-sq. & --- & --- & $11 \%$ & $14 \%$ & $21 \%$ & $9 \%$ \\
\hline
\end{tabular}

Entries are the adjusted regression coefficient (beta). ${ }^{*} \mathrm{p}<.05,{ }^{* *} \mathrm{p}<.01 ;{ }^{* * *} \mathrm{p}<.001$. 
PURPOSES AND TARGETS OF POLICING

Table 8. The influence of procedural elements on overall evaluations of procedural justice/legitimacy.

\begin{tabular}{|c|c|c|c|c|c|}
\hline & \multicolumn{3}{|c|}{ Non-Muslim } & \multicolumn{2}{|c|}{ Muslim } \\
\hline & $\begin{array}{c}\text { Minorities } \\
\text { on crime } \\
(n=1003)\end{array}$ & $\begin{array}{l}\text { Whites on } \\
\text { crime } \\
(n=550)\end{array}$ & $\begin{array}{c}\text { Non-Muslim } \\
\text { on terror\#\# } \\
(\mathbf{n}=\mathbf{2 0 0})\end{array}$ & $\begin{array}{c}\text { Crime\# } \\
(n=200)\end{array}$ & $\begin{array}{c}\text { Terror\# } \\
(n=300)\end{array}$ \\
\hline & Targeted & --- & --- & --- & Targeted \\
\hline Voice & 0.05 & $0.14^{*}$ & 0.07 & 0.08 & 0.00 \\
\hline Neutrality & $0.30 * * *$ & $0.34 * * *$ & 0.16 & $0.19^{\wedge}$ & $0.33 * * *$ \\
\hline Trust & $0.23 * * *$ & $0.23 * * *$ & $0.29 * *$ & $0.28 * *$ & $0.24 * * *$ \\
\hline Respect & $0.24 * * *$ & $0.18 * * *$ & $0.33 * *$ & $0.31^{* *}$ & $0.31^{* * *}$ \\
\hline $\begin{array}{l}\text { Time in } \\
\text { the US }\end{array}$ & --- & --- & --- & --- & --- \\
\hline $\begin{array}{l}\text { English in } \\
\text { home? }\end{array}$ & --- & --- & --- & --- & --- \\
\hline $\begin{array}{l}\text { South } \\
\text { Asia }\end{array}$ & --- & --- & --- & --- & --- \\
\hline $\begin{array}{l}\text { Middle } \\
\text { East }\end{array}$ & --- & --- & --- & --- & --- \\
\hline Age & $.06 *$ & $.08^{*}$ & --- & --- & --- \\
\hline Education & $-.07 *$ & .04 & --- & --- & --- \\
\hline Income & -.03 & .01 & --- & --- & --- \\
\hline Gender & .04 & .03 & --- & --- & --- \\
\hline Race & $-.10 * * *$ & --- & --- & --- & --- \\
\hline $\begin{array}{ll}\text { Adj. } & \text { R.- } \\
\text { sq. } & \\
\end{array}$ & $56 \%$ & $63 \%$ & $51 \%$ & $49 \%$ & $40 \%$ \\
\hline
\end{tabular}

\#The Muslim attribute variables and demographics were not found to influence these dependent variables.

\#\#Demographic variables did not significantly influence the dependent variable.

Entries are the adjusted regression coefficient (beta). ${ }^{*} \mathrm{p}<.05,{ }^{* *} \mathrm{p}<.01 ;{ }^{* * *} \mathrm{p}<.001$. 


\section{PURPOSES AND TARGETS OF POLICING}

\section{Appendix A. Samples}

All of the surveys were conducted by Abt SRBI. This research was conducted with support from the National Institute for Justice; the Law and Social Science program of the U.S. National Science Foundation (NSF0751874) and a grant from the the Open Society Institute.

General population.

General population of New York City interviewed about crime $(n=1,653)$. This study was conducted in the summer of 2002. It is based upon a stratified random sample of the residents of New York City interviewed in English or Spanish over the telephone. The sample was 25\% Hispanic; 28\% White; 34\% African-American; and 13\% other. The median age category was $35-54$ and $46 \%$ were male. Fifty-four percent made over $\$ 40,000$ and $44 \%$ were college graduates or more. The response rate was $64 \%$. Of the $13 \%$ "other" 60 respondents (4\%) reported that they were from countries that might suggest they were Muslim (for example, Pakistan). However, religion was not asked.

General population of New York City interviewed about terrorism $(n=200)$. The mean age of the same was 52 and 48 percent were male. Interviews were conducted in English and Spanish. The sample was 18\% Hispanic; 46\% White; 31\% African-American and $5 \%$ other. Sixty-one percent made over $\$ 40,000$ a year and $46 \%$ were college graduates or more. Sixty-seven percent were born in the United States and the respondents had lived an average of 6.59 years outside the US. Of the people interviewed 5 self-reported as Hindi/Muslim in the religion category (3\%). These people were included as minority respondents.

The response rate for non-Muslim interviews about terrorism was $23 \%$. This is a relatively low response rate in comparison to the other surveys. It occurred because of an atypically large number of partial non-completes. We believe this was due to the respondent's lack of knowledge about and interest in anti-terror policing activities which were generally not directed at them. For example, asking respondents whether they would report terrorists living next door or would report people sending money to Muslim organizations was less relevant to non-Muslims. Fortunately the percentage of college graduates in both general New York city samples is very similar (46\% versus $44 \%$ for the general population sample) suggesting that those who did complete the terror survey were similar to those in the larger sample of people interviewed about crime.

Muslims.

The sample of Muslims was not based upon random digit dialing because of the difficulty of finding members of this population. Instead, a sample was created using a multipart approach. First, the proportion of Muslims in each areas of the city was estimated based upon 2000 census tract information about the percentage of the population within each census tract that reported Muslim ancestry, was born in a Muslim country, or spoke a principal language of that country and about the number of mosques. These four variables were summed into a scale and then used to distinguish four levels of Muslim population based on the projected Muslim American proportion from each geographical area. A list was then acquired of known Muslim American households from list sample provider Experian. That list was sampled from in proportion to the estimated Muslim-American population in each geographical area. 


\section{PURPOSES AND TARGETS OF POLICING}

Each household was approached by telephone. Only land lines were used, but statistical adjustments were made for the number of land and cell phone numbers in the home. Homes were called back 10 times. If contact was made a randomly selected person was interviewed. Interviews were conducted in English, Bengali, Urdu or Arabic.

Muslim-Americans in New York City interviewed about terrorism $(n=300)$. The response rate was $47 \%$. The mean age of the same was 38 and 47 percent were male. Most interviews were conducted in English (73\%), with other interviews conducted in Arabic, Bengali and Urdu. Of those interviewed 19\% were born in the United States. On average the sample had spent 18 years living outside the United States. Fifty two percent were college graduates and 54\% made over $\$ 40,000$ a year.

Muslim-Americans in New York City interviewed about crime $(n=200)$. The response rate was $43 \%$. The mean age of the same was 42 and 48 percent were male. Most interviews were conducted in English (77\%), with other interviews conducted in Arabic, Bengali and Urdu. Of those interviewed 13\% were born in the United States. On average the sample had spent 20 years living outside the United States. Fifty one percent were college graduates and 53\% made over $\$ 40,000$ a year. 


\section{PURPOSES AND TARGETS OF POLICING}

Appendix B. Scales.

The scales used fixed responses. For example, "strongly agree”; "agree”; “disagree" or "strongly disagree”.

In general the concepts measured were assessed using multi-item scales. However, in some cases it was not possible to do so when assessing the elements of procedural justice: voice; neutrality; trust; and treatment with respect. This introduces a potential weakness because the reliability of single or even two-item scales is either not assessable or is not clearly assessable. However, because there is a large prior literature that identifies these elements and validates the questions used to measure them, we felt that this approach was reasonable in this study (see Tyler, 2007, 2008; Tyler \& Huo, 2002). However, it is important to be cautious in interpreting these findings.

Muslims and crime $(n=200)$

Alert police. A three item scale was constructed. Respondents were asked how likely they would be to seek help: "To report a crime occurring in your community"; "To help the police to find someone suspected of committing a crime by providing the police with information" and "If you saw a person being robbed".

Cooperate with the police. A three item scale was constructed. Respondents were asked: How likely would you be to: "Volunteer you time on nights or weekends to help the police in your community"; "Volunteer to attend a community meeting to discuss crime in your community"; or "Patrol the streets as part of a neighborhood watch program”.

Legitimacy. A six item scale was constructed. Respondents were asked: Would you agree or disagree with the following statements about the local police in your neighborhood. "These law enforcement agents are legitimate authorities and you should obey their decisions"; "You should accept the decisions made by these law enforcement agents even when you disagree with them"; "It is our duty to obey all law enforcement agents, even when we do not like the way that they treat us"; "You have confidence that the law enforcement agents in your neighborhood are doing their jobs well"; "You trust these law enforcement agents to make decisions that are good for everyone": and "People’s rights are generally well-protected by law enforcement agents".

Procedural justice-policy formation. Respondents were ask: How much do people in government care about your views and those of others in your community when they are... "Making decisions about what actions to take in your community to address the problems of crime and social order"; "Trying to deal with crime related problems in your community"; and "Making decisions about social and economic problems in your community”.

Procedural justice--implementation. The overall scale combined the results of five subscales.

Procedural justice. Respondents were asked: How fair or unfair are the police in terms of: "The procedures they use to handle the problems they deal with"; and "How they treat people”.

Voice. Respondents were asked: How often do law enforcement agents: "Give people a chance to express their views before making decisions”.

Neutrality. Respondents were asked: How often do the police: "Accurately understand and apply the law"; "Make their decisions based upon facts, not their personal opinions"; and "Apply the law consistently to everyone”. 


\section{PURPOSES AND TARGETS OF POLICING}

Trust. Respondents were asked: How often do the police: "Consider people's views when deciding what to do" and "Take account of the needs and concerns of the people they deal with”.

Respectful treatment. Respondents were asked: How often do the police: "Respect people’s rights" and “Treat people with dignity and respect”.

Effectiveness. Respondents were asked: How effective are the police in your neighborhood at helping people who ask them for help?

Deterrence. Respondents were asked: How likely are people to be caught and punished for breaking the following laws: "Park their cars illegally"; "Dispose of their trash or litter illegally"; "Make too much noise at night”; "Break a traffic law"; "Buy stolen goods on the street"; "Take inexpensive items from stores without paying” and "Use marijuana in a public place”.

Muslim attributes.

Proportion of life lived outside US. This variable reflects the ratio of years lived outside the United States to age.

Region of origin. There were two large groups of Muslims. One group was from South Asia (Bangladesh; Pakistan; India; Sri Lanka) and the other from the Middle East (Egypt; Jordon: Yemen: Palestine). These two concentrations were represented by dummy variables for region.

English in home. Respondents were asked whether English was the primary language spoken in their home; whether it was sometimes spoken; or whether it was seldom or never spoken.

Muslim identification. Two questions were asked to form the scale (alpha $=0.83$ ). First, "how important is religion in your daily life". Second, "how strongly do you identify as a Muslim"?

Demographics. Respondents were asked their age; their family income; and their level of education. Gender was coded by the interviewer.

Non-Muslims and crime

Alert the police. Respondents were asked: How likely would you be to: "Call the police to report a crime occurring in your neighborhood"; "Help the police to find someone suspected of committing a crime by providing them with information"; and "Report dangerous or suspicious activities in your neighborhood".

Cooperate. Respondents were asked: How likely would you be to: "Volunteer your time on nights or weekends to help the police in your community"; "Patrol the streets as part of a neighborhood watch program" and "Attend a community meeting to discuss crime in your community”.

Legitimacy. Respondents were asked to agree or disagree that: "The NYPD is a legitimate authority and people should obey the decisions that officers make"; "I have confidence that the NYPD can do its job well"; "I trust the leaders of the NYPD to make decisions that are good for everyone in the city"; "People's basic rights are well protected by the police"; "You should accept the decisions made by police, even if you think they are wrong"; and "You should do what the police tell you to do even when you don't like the way they treat you."

Procedural justice--implementation. This overall scale combines five subscales: procedural justice; voice, neutrality, trust and treatment with respect. 


\section{PURPOSES AND TARGETS OF POLICING}

Procedural justice. Respondents were asked: How fair or unfair are the police in terms of: "The procedures they use to handle the problems they deal with"; and "How they treat people”.

Voice. Respondents were asked: How often do the police: "Give people a chance to express their views before making decisions”.

Neutrality. Respondents were asked: How often do the police: “”accurately understand and apply the law"; "Make their decisions based upon facts, not their personal opinions"; "Apply the law consistently to everyone" and "Try to get the facts in a situation before deciding how to act”.

Trust. Respondents were asked: How often do the police: “Consider people's views when deciding what to do" and "Take account of the needs and concerns of the people they deal with"; “Give honest explanations for their actions”.

Treatment with respect. Respondents were asked: How often do the police: “Respect people’s rights” and “Treat people with dignity and respect”.

Effectiveness. Respondents were asked: How effective are the police in your neighborhood at helping people who ask them for help?

Deterrence. Respondents were asked: How likely are people to be caught and punished for breaking the following laws: "Park their cars illegally"; "Dispose of their trash or litter illegally"; "Make too much noise at night"; "Break a traffic law"; "Buy stolen goods on the street”; "Take inexpensive items from stores without paying” and "Use marijuana in a public place".

Police profile minorities. Respondents were asked: How often do the police in your neighborhood make the following types of decisions based upon the race or ethnic background of the people involved? How often do they do so when they decide which: "Cars to stop for possible traffic violations"; "People to stop and question on the street"; "People to arrest and take to jail?"; "People in the neighborhood to help with their problems?"; and "Areas of the neighborhood to patrol?”.

Police profile minorities because they are racist. Respondents were asked: Why might the police be more likely to stop minorities? How often is it "because the police are prejudices against the members of minority groups due to their race?”.

Police harass minorities. Respondents were asked: How often do the police in your neighborhood "Use ethnic slurs against people in your neighborhood?"; "Treat people disrespectfully because of their race?”; “Abuse people physically because of their race?”; and "Bully or intimidate people because of their race?”.

Muslims and non-Muslims reacting to terror Behaviors

Cooperation. Respondents were asked two items. The items were. How likely/unlikely would you be: "To work with law enforcement officials to educate people in your community about the dangers of terrorism and terrorists?"; and "To encourage members of your community to cooperate with law enforcement efforts to fight terrorism”.

Alert police to risks. Six types of behavior were identified. For each item the respondents were asked whether they thought that the behavior was an appropriate matter for the police to handle and whether they would report the behavior to the police. The behaviors were: "A person saying he/she had joined a group you consider politically radical”; "A person overheard discussing their decision to help plant explosives in a 


\section{PURPOSES AND TARGETS OF POLICING}

terrorist attack"; "A person visiting an internet chat room or web site in which there is material posted that supports al Qaeda”; "A person giving money to organizations that people say are associated with terrorists"; "A person talking about traveling overseas to fight for Muslims”; and “A person distributing material expressing support for al Qaeda”. The scale was constructed by combining these two sets of items multiplicatively.

Legitimacy. A six item scale was constructed. Respondents were asked to indicate their views concerning the local and national law enforcement agents engaged in activities related to the threat of terrorism. The items were: "These law enforcement agents are legitimate authorities and you should obey their decisions"; "You should accept the decisions made by these law enforcement agents, even when you disagree with them"; "It is our duty to obey all law enforcement agents, even when we do not like the way that they treat us"; "These agents generally treat all people with dignity and respect when they are investigating and prosecuting terrorism”; "You trust these law enforcement agents to make decisions that are good for everyone when they are investigating and prosecuting terrorism"; and "People's rights are generally well protected by these law enforcement agents when they are investigating and prosecuting terrorism”.

Procedural justice in policy formation. Respondents were asked how much the government cared about their views when "making decisions about what actions to take to address the threat of terrorism" and when "dealing with complaints about how antiterrorism tactics affect them”. They were also asked how often the government "convened meetings in your neighborhood to hear about community concerns about how law enforcement should deal with the threat of terrorism".

Procedural justice in policy implementation. The overall scale was created by combining five scales: procedural justice, voice, neutrality, trust and treatment with respect.

Procedural justice. Respondents were asked: When law enforcement agents are dealing with people like yourself concerning issues of terrorism, how fair are they in terms of: "the procedures they use to handle the problems they deal with" and "how they treat people"

Voice. Respondents were asked one item: How often do law enforcement agents. "Give people a chance to express their views before making decisions".

Neutrality. Respondents were asked: How often do law enforcement agents. The items were: "accurately understand and apply the law"; "Make their decisions based upon facts, not their personal opinions"; and "Apply the law consistently to everyone, regardless of who they are".

Trust in authorities. Respondents were asked two items: How often do law enforcement agents. "Consider people's views when deciding what to do"; and "Take account of the needs and concerns of the people they deal with"

Treatment with respect. Respondents were asked: How often do law enforcement agents: "Respect people's rights"; and "Treat people with dignity and respect"

Terror threat. Respondents were asked to agree or disagree that: "There is a serious risk of a major terrorist attack in the United States at this time”.

The police help you feel safe. Respondents were asked: "How good of a job have law enforcement agents done in terms of making you feel safe from the threat of terrorism?”. 


\section{PURPOSES AND TARGETS OF POLICING}

Police effectiveness. Respondents were asked: "If someone were planning a terrorist attack in New York City today, how likely do you think it is that they would be caught in advance?”.

Police behavior

Public behavior. Respondents were asked how often the police: "Search bags at subway stations"; "Come to people’s homes to ask questions"; "Single out people walking on the streets for stops, questioning or searches based upon their ethnicity/religion"; "Single out people for greater attention at immigration or at airport security"; "Investigate people because they send money to family overseas"

Private behavior. Respondents were asked how often the police: "Use community-based informants who are placed in Mosques or community organizations"; "Conduct electronic surveillance of Mosques or community organizations"; and "Listen to people’s telephone calls or read people’s e-mail messages”.

Police harassment of Muslims.

Non-Muslim views about whether the police harass Muslims. How frequently would you say that the police: "Are especially suspicious of Muslims" and "Treat Muslims disrespectfully or rudely"

Non-Muslim views about whether the police target Muslim community. Respondents were asked: “Compared to before September $11^{\text {th }}$ 2001have law enforcement agencies targeted their activities toward particular ethnic/religious communities much more often, more often, about as often, less often or much less often? Muslim attributes

Proportion of life lived outside US. This variable reflects the ratio of years lived outside the United States to age.

English in home. Respondents were asked if they grew up speaking English in their home. Forty-seven percent said yes.

Region of origin. There were two large groups of Muslims. One group was from South Asia (Bangladesh; Pakistan; India; Sri Lanka) and the other from the Middle East (Egypt; Jordon: Yemen: Palestine). These two concentrations were represented by dummy variables for region.

Muslim identification. Four questions were asked to form the scale (alpha $=0.82$ ). The questions were: "Being a Muslim is important to the way you think of yourself as a person.”; "You are proud to be a Muslim"; "What Islam stands for is important to you."; and "When someone praises Islam, it feels like a personal compliment".

Demographics education;

Respondents were asked about their annual family income; their level of and their age. Gender was recorded by the interviewer. 
PURPOSES AND TARGETS OF POLICING

Appendix C

Indicators used with crime

\begin{tabular}{|l|l|l|l|l|l|l|}
\hline & \multicolumn{2}{|c|}{ Muslim (n= 200) } & \multicolumn{2}{c|}{ White (n= 550) } & \multicolumn{2}{c|}{ Non-White (n= 1103) } \\
\hline & range & $\begin{array}{c}\text { Mean } \\
\text { (s.d.) }\end{array}$ & range & $\begin{array}{c}\text { Mean } \\
\text { (s.d.) }\end{array}$ & range & $\begin{array}{c}\text { Mean } \\
\text { (s.d.) }\end{array}$ \\
\hline Alert police & $1-4$ & $3.69(0.48)$ & $1-4$ & $3.38(0.46)$ & $1-4$ & $1.48(0.63)$ \\
\hline Cooperate & $1-4$ & $2.72(0.85)$ & $1-4$ & $2.62(0.83)$ & $1-4$ & $3.52(0.83)$ \\
\hline Legitimate & $1-4$ & $3.08(0.69)$ & $1-4$ & $3.11(0.56)$ & $1-4$ & $2.92(0.62)$ \\
\hline Effectiveness & $1-4$ & $3.29(0.69)$ & $1-4$ & $3.36(0.69)$ & $1-4$ & $2.88(0.77)$ \\
\hline PJ & $1-4$ & $3.14(0.69)$ & $1-4$ & $3.71(0.56)$ & $1-4$ & $3.25(0.83)$ \\
\hline Voice & $1-4$ & $2.99(1.04)$ & $1-4$ & $3.13(0.84)$ & $1-4$ & $2.84(1.04)$ \\
\hline Neutrality & $1-4$ & $3.32(0.72)$ & $1-4$ & $3.28(0.66)$ & $1-4$ & $2.98(0.76)$ \\
\hline Trust & $1-4$ & $3.07(0.83)$ & $1-4$ & $3.20(0.69)$ & $1-4$ & $2.89(0.85)$ \\
\hline Respect & $1-4$ & $3.50(0.66)$ & $1-4$ & $3.41(0.69)$ & $1-4$ & $3.05(0.88)$ \\
\hline $\begin{array}{l}\text { Harass } \\
\text { minorities }\end{array}$ & --- & -- & $1-4$ & $1.30(0.53)$ & $1-4$ & $1.78(0.87)$ \\
\hline $\begin{array}{l}\text { Profile } \\
\text { minorities }\end{array}$ & --- & --- & $1-4$ & $1.81(0.83)$ & $1-4$ & $2.44(1.00)$ \\
\hline $\begin{array}{l}\text { Profile due } \\
\text { to racism }\end{array}$ & --- & --- & $1-4$ & $2.26(1.03)$ & $1-4$ & $2.89(1.02)$ \\
\hline
\end{tabular}


PURPOSES AND TARGETS OF POLICING

Indicators used with terrorism

\begin{tabular}{|l|l|l|l|l|}
\hline & \multicolumn{2}{|c|}{$\begin{array}{c}\text { Non-Muslims } \\
\text { (n= 200) }\end{array}$} & \multicolumn{2}{c|}{$\begin{array}{l}\text { Muslims } \\
\text { (n= 300) }\end{array}$} \\
\hline & range & Mean (s.d.) & range & Mean (s.d.) \\
\hline Cooperation & $1-4$ & $3.09(0.91)$ & $1-4$ & $3.36(0.73)$ \\
\hline Police should be concerned & $1-4$ & $3.69(0.40)$ & 1.4 & $3.51(0.53)$ \\
\hline I would contact the police & $1-4$ & $3.43(0.66)$ & $1-4$ & $3.41(0.64)$ \\
\hline Legitimacy & $1-4$ & $2.66(0.57)$ & $1-4$ & $2.88(0.55)$ \\
\hline PJ -formation & $1-4$ & $2.12(0.83)$ & $1-4$ & $2.53(0.87)$ \\
\hline PJ-implementation & $1-4$ & $3.09(0.74)$ & $1-4$ & $2.71(0.78)$ \\
\hline Voice & $1-4$ & $2.46(1.10)$ & $1-4$ & $2.86(1.04)$ \\
\hline Neutrality & $1-4$ & $3.09(0.79)$ & $1-4$ & $3.17(0.74)$ \\
\hline Trust & $1-4$ & $2.62(0.91)$ & $1-4$ & $2.90(0.84)$ \\
\hline Interpersonal respect & $1-4$ & $3.18(0.81)$ & $1-4$ & $3.25(0.76)$ \\
\hline Police target Muslim community. & $1-4$ & $3.77(1.05)$ & --- & --- \\
\hline Police suspicious of Muslims & $1-4$ & $2.99(0.97)$ & --- & --- \\
\hline Police harass Muslims & $1-4$ & $2.49(0.99)$ & --- & --- \\
\hline Terror threat real & $1-4$ & $3.14(0.72)$ & $1-4$ & $2.27(0.84)$ \\
\hline Police feel safe & $1-4$ & $2.83(0.68)$ & $1-4$ & $2.98(0.69)$ \\
\hline Police effective & $1-4$ & $2.90(0.88)$ & $1-4$ & $3.15(0.94)$ \\
\hline
\end{tabular}


PURPOSES AND TARGETS OF POLICING

\begin{tabular}{|c|c|c|}
\hline \multicolumn{3}{|c|}{ Alphas for crime } \\
\hline & $\begin{array}{c}\text { Muslim } \\
(\mathbf{n}=\mathbf{2 0 0})\end{array}$ & $\begin{array}{l}\text { Non-Muslim } \\
(\mathrm{n}=\mathbf{1 , 6 5 3 )}\end{array}$ \\
\hline Alert police & 0.57 & 0.71 \\
\hline Cooperate & 0.72 & 0.78 \\
\hline Legitimate & 0.72 & 0.78 \\
\hline Effectiveness & --- & --- \\
\hline Deterrence & 0.80 & 0.86 \\
\hline PJ formation & 0.79 & --- \\
\hline $\begin{array}{lll}\text { Overall } & \text { PJ } \\
\text { implementation }\end{array}$ & 0.70 & 0.92 \\
\hline Harass minorities & --- & 0.89 \\
\hline Profile minorities & --- & 0.89 \\
\hline Profile due to racism & --- & --- \\
\hline
\end{tabular}

Note. Items for which no alpha is reported are single item scales. 
PURPOSES AND TARGETS OF POLICING

Alphas for terrorism

\begin{tabular}{|l|l|l|}
\hline & $\begin{array}{c}\text { Non-Muslims } \\
(\mathbf{n}=\mathbf{2 0 0})\end{array}$ & \multicolumn{1}{|c|}{$\begin{array}{c}\text { Muslims } \\
(\mathbf{n}=\mathbf{3 0 0})\end{array}$} \\
\hline Cooperation & & \\
\hline Police should be concerned & 0.71 & 0.57 \\
\hline I would contact the police & 0.69 & 0.72 \\
\hline Legitimacy & 0.84 & 0.83 \\
\hline PJ -formation & 0.81 & 0.78 \\
\hline PJ-implementation & 0.75 & 0.72 \\
\hline Police target Muslim community. & 0.81 & 0.81 \\
\hline Police suspicious of Muslims & --- & --- \\
\hline Police harass Muslims & --- & --- \\
\hline Terror threat real & --- & --- \\
\hline Police feel safe & --- & --- \\
\hline Police effective & --- & --- \\
\hline Public police behavior & --- & --- \\
\hline Private police behavior & 0.60 & 0.69 \\
\hline
\end{tabular}

Note. Items for which no alpha is reported are single item scales.

Readers with comments may address them to:

Professor Aziz Z. Huq University of Chicago Law School

1111 East 60th Street

Chicago, IL 60637

huq@uchicago.edu 


\section{The University of Chicago Law School Public Law and Legal Theory Working Paper Series}

For a listing of papers 1-275 please go to http://www.law.uchicago.edu/publications/papers/publiclaw.

276. Eric A. Posner and Adrian Vermeule, Tyrannophobia, September 2009

277. Bernard E. Harcourt, Henry Louis Gates and Racial Profiling: What's the Problem? September 2009

278. Lee Anne Fennell, The Unbounded Home, Property Values beyond Property Lines, August 2009

279. Brian Leiter, The Epistemic Status of the Human Sciences: Critical Reflections on Foucault, October 2009

280. Ward Farnsworth, Dustin F. Guzior, and Anup Malani, Ambiguity about Ambiguity: An Empirical Inquiry into Legal Interpretation, October 2009

281. Anup Malani, Oliver Bemborn and Mark van der Laan, Accounting for Differences among Patients in the FDA Approval Process, October 2009

282. Saul Levmore, Ambiguous Statutes, November 2009

283. Rosalind Dixon, Female Justices, Feminism and the Politics of Judicial Appointment: A Reexamination, November 2009

284. Rosalind Dixon, The Supreme Court of Canada, Charter Dialogue and Deference, November 2009

285. Rosalind Dixon, A Minimalist Charter of Rights for Australia: The U.K. or Canada as a Model? November 2009

286. F. Scott Kieff and Richard A. Epstein, Supreme Court Brief of Dr. Ananda Chakrabarty as Amicus Curiae in Support of Petitioners in Bilski (December 2009)

287. Jacob E. Gersen and Anne Joseph O’Connell, Hiding in Plain Sight? Timing and Transparency in the Administrative State (December 2009)

288. Richard A. Epstein, Impermissible Ratemaking in Health-Insurance Reform: Why the Reid Bill Is Unconstitutional (December 2009)

289. Brian Leiter, Why Legal Positivism? (December 2009)

290. Anu Bradford and Eric A. Posner, Universal Exceptionalism in Internatinal Law (February 2010)

291. Daniel Abebe and Eric A. Posner, Foreign Affairs Legalism: A Critique (February 2010)

292. Tom Ginsburg, Eastphalia as a Return to Westphalia (February 2010)

293. Tom Ginsburg, Lawrence Friedman's Comparative Law (February 2010)

294. Tom Ginsburg, Studying Japanese Law because It’s There (February 2010)

295. Tom Ginsburg, Judicial Indipendence in East Asia: Implications for China (February 2010)

296. Tom R. Tyler, Stephen Schulhofer, and Aziz Huq, Legitimacy and Deterrence Effects in Counter-Terrorism Policiing: A Study of Muslim Americans (February 2010)

297. Alison L. LaCroix, Federalists, Federalism, and Federal Jurisdiction (February 2010)

298. Brian Leiter, Rorty and the Philophical Tradition: A Comment on Professor Szubka (March 2010)

299. Aziz Z. Huq, Against National Security Exceptionalism (March 2010)

300. Anu Bradford, When the WTO Works, and How It Fails (March 2010)

301. Aziz Z. Huq, Modeling Terrorist Radicalization (March 2010)

302. Adam M. Samaha, On Law’s Tiebreakers (March 2010)

303. Brian Leiter, The Radicalism of Legal Positivism (March 2010)

304. Lee Anne Fennell, Unbundling Risk (April 2010)

305. Aziz Z. Huq, What Good Is Habeas? (April 2010)

306. Aziz Z. Huq, Easterbrook on Academic Freedom (April 2010) 
307. Jonathan S. Masur and Jonathan Remy Nash, The Institutional Dynamics of Transition Relief (April 2010)

308. Alison L. LaCroix, Temporal Imperialism (May 2010)

309. Lior J. Strahilevitz, Reunifying Privacy Law (May 2010)

310. Lee Fennell, Possession Puzzles (June 2010)

311. Jonathan S. Masur, Booker Reconsidered (June 2010)

312. Mary Anne Case, What Feminists Have to Lose in Same-Sex Marriage Litigation (July 2010)

313. Mary Anne Case, A Lot to Ask: Review Essay of Martha Nussbaum's From Disgust to Humanity: Sexual Orientation and Constitutional Law (July 2010)

314. Adam M. Samaha, The Story of FCC v. Pacifica Foundatin (and Its Second Life) (August 2010)

315. Jonathan S. Masur and Eric A. Posner, Climate Regulation and the Limits of Cost-Benefit Analysis (August 2010)

316. Jonathan Masur, Patent Inflation (August 2010)

317. Bernard E. Harcourt and Tracey L. Meares, Randomizaton and the Fourth Amendment (August 2010)

318. Adam M. Samaha, Low Stakes and Constitutional Interpretation (August 2010)

319. Brian Leiter, The Demarcation Problem in Jurisprudence: A New Case for Skepticism (August 2010)

320. Brian Leiter, Legal Formalism and Legal Realism: What Is the Issue? (August 2010)

321. John Bronsteen, Christopher Buccafusco, and Jonathan S. Masur, Retribution and the Experience of Punishment (September 2010)

322. Lior Strahilevitz, Pseudonymous Litigation (September 2010)

323. Bernard E. Harcourt, Risk As a Proxy for Race (September 2010)

324. Christopher R. Berry and Jacob E. Gersen, Voters, Non-Voters, and the Implications of Election Timing for Public Policy, September 2010

325. Lee Anne Fennell, Willpower Taxes, October 2010

326. Christopher R. Berry and Jacob E. Gersen, Agency Design and Distributive Politics, October 2010

327. Eric A. Posner, The Constitution of the Roman Republic: A Political Economy Perspective, November 2010

328. Tom Ginsburg, James Melton and Zachary Elkins, On the Evasion of Executive Term Limits, November 2010

329. Rosalind Dixon and Eric A. Posner, The Limits of Constitutional Convergence, November 2010

330. Tom Ginsburg, Constitutional Specificity, Unwritten Understandings and Constitutional Agreement, November 2010.

331. Tom Ginsburg, Written Constitutions and the Administrative State: On the Constitutional Character of Administrative Law, November 2010

332. Rosalind Dixon, Amending Constituting Identity, December 2010

333. Eric A. Posner and Adrian Vermeule, Demystifying Schmitt, January 2011

334. Jonathan S. Masur, Regulating Patents, January 2011

335. Bernard E. Harcourt, Reducint Mass Incarceration: Lessons from the Deinstitutionalization of Mental Hospitals in the 1960s, January 2011

336. Jacob E. Gersen, Designing Agencies, January 2011

337. Stephen J. Schulhofer, Tom R. Tyler, and Aziz Z. Huq, American Policing at a Crossroads, February 2011

338. Aziz Z. Huq, The Signaling Function of Religious Speech in Domestic Counterterrorism, February 2011 


\section{PURPOSES AND TARGETS OF POLICING}

339. Aziz Z. Huq, Tom R. Tyler, and Stephen J. Schulhofer, Why Does the Public Cooperate with Law Enforcement? The Influence of the Purposes and Targets of Policing, February 2011 